\title{
Educação Profissional e Tecnológica no Contexto da Internacionalização da Educação
}

\author{
Dossiê Temático \\ Darlan Marcelo Delgado ${ }^{1}$ \\ Vagno Emydio Machado Dias²
}

A última metade do século $X X$ marcou uma série de complexas transformações políticas, econômicas e culturais que tiveram significativos desdobramentos na educação mundial. $O$ processo de deterioração do Welfare State - e as reformas dos Estados nacionais com a respectiva ressignificação de seus papeis como produtores e condutores de políticas públicas e sociais - guiado por políticas econômicas de orientação neoclássica (o chamado "novo consenso macroeconômico") produziu diversas consequências e gerou diversos desdobramentos. A mercantilização da educação e o seu processo de internacionalização são alguns resultados emblemáticos. A Educação Profissional e Tecnológica (EPT), dada sua inerente função de formação para o trabalho e para o atendimento das necessidades da produção de bens e serviços na sociedade, foi alçada a política educacional estratégica por organismos internacionais e multilaterais como a Unesco e o Banco Mundial, no sentido do enfrentamento dos desafios de formação profissional, como lócus em geração de inovações e soluções técnicas e tecnológicas dirigidas às organizações e, adicionalmente, como política potencialmente capaz de apaziguar o problema do desemprego de jovens e adultos, promover políticas de inclusão social e das mulheres no mundo do trabalho e gerar soluções ecológicas e sustentáveis para a chamada economia verde. Todas estas mudanças ocorrem ainda no cenário em que as novas tecnologias de base digital substituíram de modo veloz e avassalador as tradicionais tecnologias de base analógica. A produção industrial e a oferta de serviços foram revolucionadas desde o chão de fábrica até os escritórios, assim como as dimensões da concepção e da execução do trabalho. O regime de acumulação flexível e sua base pedagógica calcada na concepção educacional da pedagogia das competências colocou em xeque as tradicionais ocupações e suas respectivas qualificações profissionais. Neste contexto de inauditas e céleres transformações, o emprego formal passou a ceder cada vez mais lugar à capacidade empreendedora de indivíduos que se encontram à própria sorte nos distintos mercados, sendo que o mercado de trabalho formal se encontra cada vez mais encolhido. A globalização dos mercados e a financeirização da economia passaram a conduzir toda a atividade econômica em dimensão planetária. Sendo assim, a Revista Brasileira de Educação Comparada (RBEC) publica o presente dossiê com resultados de estudos teóricos e analíticos e/ou de pesquisas concluídas a partir de análises estatísticas ou quantitativas sobre a temática da Educação Profissional e Tecnológica em suas múltiplas possibilidades de imbricação com o processo de internacionalização da Educação.

\footnotetext{
${ }^{1}$ Centro Estadual de Educação Tecnológica Paula Souza.

E-mail: profdarlandelgado@gmail.com | ORCID: https://orcid.org/0000-0003-3177-2364

${ }^{2}$ Instituto Federal de Educação, Ciência e Tecnologia do Sul de Minas Gerais (Poços de Caldas).

E-mail: vagno.dias@ifsuldeminas.edu.br | ORCID: https://orcid.org/0000-0001-9102-4283
} 